\title{
Detection of fetomaternal haemorrhage by an immunofluorescence technique
}

\author{
AC McWILLIAM, SALLY C DAVIES \\ From the Department of Haematology, Central Middlesex Hospital, London
}

SUMMARY An inexpensive and simple technique for assessing fetomaternal bleeds in cases of $\mathrm{Rh}(\mathrm{D})$ incompatibility is described. The method is unlikely to replace the acid elution technique, but it may be of use in cases where results are in doubt owing to the presence of $F$ cells of maternal origin.

Sensitisation of $R h(D)$ negative mothers by $R h(D)$ positive fetuses has been greatly reduced by the prophylactic administration of anti- $\mathrm{D}\left(\mathrm{Rh_{0 }}\right)$ immunoglobulin.'

In the United Kingdom $500 \mathrm{IU}$ of anti- $\mathrm{D}\left(\mathrm{Rh}_{0}\right)$ immunoglobulin is routinely given post partum to all $\mathrm{Rh}(\mathrm{D})$ negative mothers who have given birth to $\mathrm{Rh}(\mathrm{D})$ positive babies. This is considered adequate for most deliveries except when there has been a fetomaternal bleed of more than $4 \mathrm{ml}^{2}$

Fetomaternal haemorrhage is usually assessed by the detection of cells containing fetal haemoglobin ( $F$ cells) in the mother's circulation using a modification of the acid elution technique. ${ }^{3}$ This technique is adequate for most cases. Some patients, however, may have autochthonously raised concentrations of haemoglobin $F$, which is often unevenly distributed, and some of these cells may stain heavily resulting in difficulties in distinguishing them from cells of fetal origin. Raised haemoglobin $F$ concentrations may be seen in apparently normal adults of both Causcasian and Negro origin, although it is more commonly seen in Negroes, particularly in association with sickle cell disease and trait and in heterozygous $\beta$ thalassaemia. ${ }^{45}$

We have found that patients with raised haemoglobin $\mathrm{F}$ concentrations cause considerable problems and concern when attempting to assess fetomaternal haemorrhage (see case history below), even when the recommendations laid down by the Association of Clinical Pathologists ${ }^{2}$ for such patients are followed. The technique described here eliminates these problems of assessing haemorrhage when the results of the acid elution method may be in doubt.

Accepted for publication 18 April 1985

\section{Case History}

A 33 year old Nigerian woman presented at term $($ para II +1$)$. Two days later she underwent a normal vaginal delivery, at which time her blood was grouped as $\mathrm{O} R \mathrm{R}(\mathrm{D})$ negative and the cord blood as $\mathrm{O} R \mathrm{Rh}(\mathrm{D})$ positive with a negative direct antiglobulin test. The acid elution technique, carried out using a commercial kit (Boehringer Mannheim), showed 60-70 F cells per low power field with a variable intensity of staining. The haemoglobin $\mathrm{F}$ was quantitated and shown to be $6 \%$. Anti-Rh(D) immunoglobulin (500 IU) was given. Tests were repeated after three weeks and haemoglobin $F$ concentrations were unchanged. Free anti-D was detected in the serum, suggesting that any $R h(D)$ positive cells had been successfully removed. Using an automated cell counter (Technicon H6000), we were unable to show a population of macrocytic cells, which could have been of fetal origin, either immediately post partum or at three weeks. Repeat testing requested for six months post partum proved impossible as she had returned to Nigeria.

\section{IMMUNOFLUORESCENCE TECHNIQUE}

The patient's red cells, taken into potassium edetic acid, were washed four times in filtered normal saline, and finally resuspended in low ionic strength saline (Lorne Laboratories) to a concentration of $3 \%$. Fifty microlitres of red cells was mixed with 50 $\mu l$ of anti-D serum (Novasera, Ortho Laboratories) and incubated at $37^{\circ} \mathrm{C}$ for 15 minutes. After centrifugation at $110 \mathrm{~g}$ for 30 seconds the samples were washed three times in filtered saline. Fifty microlitres of a 1/40 dilution of sheep antihuman globulin labelled with fluorescein isothiocyanate (Well- 
come Laboratories) was mixed with the test cells and incubated at room temperature for 30 minutes. After three more washes in filtered saline the tests were read as a wet preparation with a Leitz SM Lux microscope using a $\times 10$ eyepiece and $\times 63$ objective.

Fields were selected under phase contrast and the total numbers of cells were determined. The fields were then examined under ultraviolet light, and fluorescing cells were counted.

Positive and negative controls were carried out with each series of tests, the positive control consisting of a 1/1000 dilution of group $\mathrm{O} R \mathrm{~h}(\mathrm{D})$ positive cells in $R h(D)$ negative cells.

\section{Discussion}

With this technique $\mathrm{Rh}(\mathrm{D})$ positive cells fluoresce intensely and $R h(D)$ negative cells show no fluorescence. Background fluorescence and non-specific binding of sheep antihuman globulin labelled with fluorescein isothiocyanate have not been found to be a problem. The method takes 90 minutes and is inexpensive, using only routine reagents and equipment.

Three $\mathrm{Rh}(\mathrm{D})$ negative mothers with raised $\mathrm{Hb} \mathrm{F}$ concentrations and uneven distribution gave birth to $\mathrm{Rh}(\mathrm{D})$ positive babies at this hospital in 1984. The first two gave rise to considerable concern because with the acid elution technique it was not possible to prove that moderate fetomaternal haemorrhage was not being masked by the presence of $F$ cells of maternal origin. In the third patient, however, with the introduction of the immunofluorescence technique we established with confidence that any fetomaternal haemorrhage was less than $4 \mathrm{ml}$.

A fluorescence activated cell sorter has been used to show small fetomaternal bleeds. ${ }^{6}$ The method is far more sensitive than the one described here because the cell sorter can check five million cells per sample. It takes six hours to complete, however, and is considered to be only a research tool by the authors themselves. Also, since 500 IU of anti-D immunoglobulin is routinely given to all $R h(D)$ negative mothers with $R h(D)$ positive babies the detection of such a minor population of fetal cells is of little importance. A 500 IU dose of anti-D immunoglobulin is considered enough to ensure destruction of a $4 \mathrm{ml}$ bleed, which represents a ratio of fetal red cells to maternal red cells of about 1:1500. We believe that checking 4000 cells using the immunofluorescence technique is adequate to detect any clinically important fetomaternal haemorrhage.

If more than two fluorescing cells are seen in about 4000 non-fluorescing cells, the severity of the bleed can be assessed using the following equation;

Number of fluorescing cells $\times 6000$

Number of non-fluorescing cells $=$ Fetal bleed $(\mathrm{ml})$.

The dose of anti-D immunoglobulin required is based on the assumption that 125 IU of anti-D immunoglobulin will clear $1 \mathrm{ml}$ of $\mathrm{Rh}(\mathrm{D})$ positive cells.

We thank Mr CAJ Falcon for his help in developing this technique.

\section{References}

' Tovey LAD, Murray J, Stevenson BJ, Taverner JM. Prevention of Rh haemolytic disease. Br Med J 1978;ii: 106-8.

${ }^{2}$ Wagstaff $W$. Practical aspects of anti-D prophylaxis of haemolytic disease of the newborn. Association of Clinical Pathologists, 1978, Broadsheet 90.

${ }^{3}$ Mollinson PL. Blood transfusion in clinical medicine. 6th ed. Oxford: Blackwell Scientific Publications, 1979.

${ }^{4}$ Stamatoyannopoulos G, Wood WG, Papayannopoulou T, Nute PE. A new form of hereditary persistence of fetal hemoglobin in Blacks and its association with sickle cell trait. Blood 1975; 46: 683-92.

${ }^{5}$ Wood WG, Stamatoyannopoulos G, Lim G, Nute PE. F-cells in the adult: normal values and levels in individuals with hereditary and acquired elevations of HbF. Blood 1975;46:671-82.

- Medearis AL, Hensleigh PA, Parks DR, Herzenberg LA. Detection of fetal erythrocytes in maternal blood post partum with the fluorescence-activated cell sorter. Am J Obstet Gynecol 1984; 148: 290-5.

Request for reprints to: Mr AC McWilliam, Haematology Department, Central Middlesex Hospital, Acton Lane, London NW10 7NS, England. 